\title{
SELF-EMPLOYMENT: INFLUENCE OF TAX INCENTIVES AND INCOME UNDERREPORTING*
}

\section{Adam Adamczyk ${ }^{a}$}

\begin{abstract}
The aim of the article is to answer the question whether the tax benefits that can be obtained by the self-employed in Poland influence the decision to start their own business. In the study, the EUROMOD microsimulation model is used to determine tax benefits from self-employment. The estimated tax benefits are then used in a probit regression to explain the probability of self-employment. The survey is carried out for both original EU-SILC data and adjusted data, assuming that the income reported by the self-employed is underreported. The results of the survey based on the original data indicate that taxpayers make irrational decisions about taking up self-employment. This is because as the benefits of self-employment increase, the probability of self-employment decreases. After adjusting the data on self-employed income with the underreported income, the results of the analysis lead to the opposite conclusion.
\end{abstract}

Keywords: self-employment, taxation, underreporting

JEL Classification: J38, J08, H30, L53

* The results were achieved using the EUROMOD model, version I2.0 +. EUROMOD is maintained, developed and managed by the Institute for Social and Economic Research (ISER) at the University of Essex, in cooperation with national teams from EU member states. I am grateful to the many people who contributed to the development of EUROMOD. The process of expanding and updating EUROMOD is supported financially as part of the EaSI EU programme for employment and social innovation (2014-2020). Responsibility for the results and their interpretation is that of the author.

The author would like to thank the participants in seminars in the Centre for Economic Analysis, CenEA (Szczecin), and in particular Michał Myck and Leszek Morawski, for their valuable comments on earlier versions of this work.

The project is financed within the framework of the programme of the Minister of Science and Higher Education under the name "Regional Excellence Initiative" in the years 2019-2022; project number 001/RID/2018/19.

a University of Szczecin, Szczecin, Poland Email: adam.adamczyk@usz.edu.pl 


\section{Introduction}

Although there is a great deal of literature on state support for self-employment, this problem is still controversial. This relates both to the justification of support for self-employment and to the choice of the form of state aid. The key problem to be solved when deciding whether and how to support self-employment is the answer to the question whether state policy aimed at helping the self-employed is effective. Tax preferences are one of the most common forms of state aid for the self-employed. Therefore, a lot of research is devoted to the answer to the question whether taxation affects self-employment decisions. However, the results of analyses of the relationship between taxation and self-employment are often contradictory. The question therefore arises as to what factors determine the wide variation in the results of studies on the impact of taxation on self-employment. One of the reasons for the differences in research results may be that the self-employed underreport their income. The scale of income underestimation varies from country to country and depends on the quality of state institutions (Torrini, 2005). The underreporting of income by the selfemployed may therefore affect differences in research findings between countries. Although the literature often mentions that the incentive to become self-employed is that there is a greater possibility of underreporting taxable income than in the case of employees, at the same time it is assumed that the statistical data on self-employed income used in the research are not understated. However, there are a number of studies indicating that the self-employed understate their income data not only in tax returns but also in surveys carried out by statistical offices. The aim of this article is therefore to examine whether taxation affects the taking up of self-employment and to answer the question whether the phenomenon of underreporting of income may distort the results of research into the relationship between taxation and self-employment. So far, research into the impact of taxation on self-employment has been conducted mainly in countries with strong institutions such as the United Kingdom, Germany, Sweden, Canada or the USA, where the significance of income understatement is relatively lower. Therefore, to highlight the impact of underreporting income by the self-employed on the research results, data from Poland, i.e., a country which, due to weaker institutions, is exposed to the problem on a larger scale, were used.

In the first stage of the survey, the EUROMOD microsimulation model and micro data for Polish households from the European Union Statistics on Income and Living Conditions (EU-SILC) ${ }^{1}$ are used. The microsimulation model makes it possible

1 This paper is based on data from Eurostat, European Union Statistics on Income and Living Conditions, 2013-2016. The responsibility for all conclusions drawn from the data lies entirely with the author. 
to determine the tax benefits that taxable persons may obtain by changing the form of work provision from employment to self-employment. The variable so determined is used to build a probit model of self-employment. In the second stage of the survey, data on self-employment income are adjusted to take into account the phenomenon of income underreporting. The income adjustment is made using estimates by Kukk et al. (2019) of the phenomenon of self-employment income underreporting. The tax benefits of selfemployment are then recalculated for the adjusted data and used to build a new probit model of self-employment.

The results obtained indicate that the self-employment model built on the basis of unadjusted self-employed income leads to conclusions that are not as expected. The analysis of this model shows that as the potential tax benefits of self-employment increase, the likelihood of taking up this form of work provision decreases. When the adjustment of self-employed income with the underreported income is taken into account, the results of the model become as expected, leading to the conclusion that the increase in tax benefits from self-employment has a positive impact on the likelihood of taking up self-employment.

\section{Taxation as a Factor Shaping Self-employment}

Using tax policy to support self-employment only makes sense if it is shown that taxes can have an effect on self-employment. To this end, it would be useful to analyse the literature on the factors influencing the propensity to become self-employed, so as to identify the channels for the impact of taxation on self-employment.

Willingness to become self-employed may be influenced by the characteristics of the environment in which the person operates or by the individual characteristics of the person concerned. Among the characteristics of the environment influencing decisions to take up self-employment are state policy, macroeconomic trends, education, industrial structure, capital, infrastructure, knowledge transfer, cultural norms and values (Wagner and Sternberg, 2004). Taxation is an element of state policy that interacts with individual determinants of engaging in business activity.

In the literature devoted to individual determinants of self-employment such factors as gender, education, age, risk aversion, professional experience, race, origin, marital status, number of children, nationality and financial resources are mentioned. A detailed overview of individual self-employment determinants can be found in Simoes et al. (2016).

Taxation can have an indirect effect on decisions about self-employment by influencing some of these determinants. Tax solutions can, for example, create incentives to raise education. Tax structures may also encourage people to have children or change their 
marital status. Taxation also affects income earned by potential entrepreneurs and thus their financial resources. However, the indirect impact of taxation on self-employment, if it occurs, is rather weak and significantly delayed.

Taxes can also influence self-employment decisions by directly shaping the relationship between the rate of return obtained by entrepreneurs and the risk they incur. The impact of taxation, especially tax progression, on the willingness to take risks may be differentiated, i.e., positive, negative and neutral, depending on the possibility of settling losses and the level of aversion towards entrepreneurial risk (Dondena et al., 2017).

The literature distinguishes three approaches to the problem of the impact of taxation on risk and choice of form of work provision. For a risk-neutral entrepreneur, proportional income tax with full loss deductibility has no impact on the decision to become selfemployed (Gentry and Hubbard, 2000).

For the same person, progressive income tax - a "success tax" with incomplete loss deductibility - reduces the propensity to become self-employed (Gentry and Hubbard, 2000; Wen and Gordon, 2014).

Finally, if the potential entrepreneur is risk-averse, progressive tax can function as insurance, creating stronger incentives for self-employment than proportional taxation (Domar et al., 1981).

The relation between income and risk may also be affected by the understatement of income by the self-employed. It results from the possibility of flexible shaping of the taxation base by entrepreneurs. This is because taxation of income from selfemployment depends on voluntary compliance with tax regulations by the entrepreneur, while the tax on salaries of employed persons is settled by employers, who are not interested in reducing their employees' tax base (Kleven et al., 2011). Secondly, many expenses related to self-employment are deductible when calculating taxable income (Bruce, 2000). The self-employed can therefore deduct part of their private consumption expenditures from their income.

The multiplicity of the effects associated with taxation leads to a situation where theoretical analyses do not provide a uniform answer to whether and how taxation affects self-employment decisions.

The results of studies on the impact of taxation on self-employment are also ambiguous. Some papers point to a positive correlation between taxation and selfemployment. Parker (1996) shows that higher marginal tax rates encourage taking up self-employment, which is consistent with the hypothesis of Long (1982) and Blau (1987) that self-employment offers greater opportunities to avoid and evade taxation. Shuetze (2000) has demonstrated the existence of a strong positive effect of the average tax rate on the male self-employment rate. On the other hand, findings of Bruce (2000) indicate 
that an increase in the marginal rate of self-employment taxation increases the likelihood of starting self-employment.

Other studies do not confirm the relationship between taxation and self-employment. According to Crum and Gohmann (2016), taxation does not have a significant impact on the creation of new businesses. Similar conclusions can be drawn from Parker (2003), according to whom the decision to become self-employed does not depend on financial factors. On the other hand, in his research on the impact of tax changes on young people's self-employment in Sweden, Egebark (2016) concluded that the level of self-employment in this group is insensitive to changes in taxation.

There are also studies showing that higher taxation can discourage people from becoming self-employed. Fossen and Steiner (2009) analysed the impact of tax reforms in Germany leading to a reduction in the marginal self-employed tax rate and proved that the reduction in taxation contributed to an increase in the likelihood of choosing selfemployment. According to Hansson (2010), both average and marginal tax rates have a negative impact on self-employment decisions.

As the studies on the impact of taxation on self-employment decisions cited above show, the conclusions in the literature differ significantly. These differences may result from the use of different survey methodologies, e.g., selection of explaining and explained variables and use of different types of models. Ambiguity in the results may also stem from the choice of the data sets used in the surveys. Some studies are based on aggregated data, others on micro data. Not without significance is also the selection of the research period and target group.

The fact that research has been carried out in different countries may also be of great importance. This is because taxpayers' reactions to taxation depend on a number of institutional, economic and cultural factors. The quality of state institutions is the key factor determining the impact of taxation on self-employment. As previously stressed, the cost-effectiveness of self-employment is determined by the possibility for taxpayers to flexibly shape their taxable base. The stronger the state institutions and the higher the quality of tax law, the smaller the potential benefits from tax avoidance and evasion. Evidence supporting this thesis is the positive relationship between the corruption perception index and the self-employment rate. (Torrini, 2005).

The results of studies on the relationship between taxation and the propensity to become self-employed may also be significantly influenced by the extent of the tax burden that has been taken into account in the analyses. Most authors focus only on income tax and omit other burdens, such as social security contributions. As will be shown later in this article, such a limitation may change the results of the research significantly. This is a consequence of the fact that most studies assume that taxation of self-employed 
income does not differ from taxation of income from employment. The only tax benefit that the self-employed can gain is the greater freedom (possibility) to shape the taxable base (by understating income). In reality, however, the differences in burdens between the selfemployed and the employed in many countries are due to differences in social security contributions between these groups. When social security contributions are included in the analysis, the profitability of self-employment may change as a function of the income earned. In a large part of the EU, the profitability of self-employment increases with the level of income earned. This means that when self-employed people underreport part of their income, their decisions to take up self-employment may seem unreasonable.

\section{Underreporting and Impact of Taxation on Choice of Self-employment}

There is a significant number of studies which indicate that underreporting of income is a key factor shaping the link between taxation and self-employment (Blau, 1987; Parker, 1996; Robson and Wren, 1999; Bruce, 2000; Schuetze, 2000; Parker and Robson, 2004). According to the studies cited above, the possibility for the self-employed to underreport their income is a factor that may encourage self-employment. However, the analysis of the impact of underreporting on the relationship between taxation and self-employment is difficult for at least two reasons. The first one is related to the need to resolve the problem of whether the income data used in the research on the impact of taxation on self-employment are reliable. Most analyses are based on data from household income statistics. Researchers usually assume that the data used in the analysis have not been manipulated by taxpayers as in the case of tax returns. However, there are indications that the legitimacy of this assumption can be questioned. As the research conducted by Hurst et al. (2013) shows, it is naive to believe that taxpayers in household surveys provide information other than that provided to the tax administration. The misstatement of data on income of self-employed households may be due to the fact that respondents are not convinced of the full confidentiality of the survey. Moreover, the self-employed often have no other information on their actual income than that provided to the tax administration. Moreover, the provision of false information for statistical purposes on the income obtained usually does not involve any penalty.

The second problem is related to the measurement of the size of the phenomenon of underreporting of income. The problem of estimating the scale of tax avoidance and evasion has a history of at least several decades. The research applies diverse methods, including ones based on analysis of the consumption of factors of production, the size of money supply or data from tax inspections. Other methods use models applied by banks to determine the actual income of borrowers (Artavanis et al., 2016). 
Our analysis of the literature indicates that there is a large variation in the estimates of the size of this phenomenon between countries and depending on the methodology used. The most common method of estimating the amount of underreported income is the approach proposed by Pissarides and Weber $(1989)^{2}$. Among researchers dealing with the problem of underreporting of income by the self-employed, this method is considered to be the work horse of modern research on tax fraud (Engström and Hagen, 2017). This approach is based on the assumption that the actual level of income of the self-employed can be determined on the basis of the size of their consumption. For this purpose, the relationship between consumption and income is used in a reference group of employed persons whose actual income is assumed to be in conformity with the income reported for tax purposes. According to Kukk et al. (2019), estimates of underreported self-employed income can range from a few to several dozen percent. The great popularity of the P\&W method and the fact that it is designed to estimate the underreporting of income by the self-employed have led to our decision to use results based on this approach for further analysis.

\section{Study Description}

Most of the research so far has focused on analysis of the impact of taxation on selfemployment in highly developed countries with well-functioning institutions such as Germany, the UK, the USA, Canada or Sweden. According to results of the research mentioned above (Torrini, 2005), the level of development of state institutions may influence the size of benefits that the self-employed gain from underreporting their income. In this article, therefore, the problem of the impact of taxation on self-employment is examined on the example of Poland, i.e., a country with a recently transformed national economy. Therefore, one can expect that the quality of institutions in Poland is not yet as high as in highly developed countries, which in turn has an impact on the larger scale of the problem of self-employed people underreporting their income.

Moreover, most of the studies so far have focused on the relationship between income taxation and self-employment, leaving aside other types of burden on the employees and the self-employed. These studies concerned mainly the impact of changes in income tax rates and tax progression on taking up self-employment. However, in most countries, self-employment income is taxed according to the same rules as employment income. As already mentioned, the differences in the taxation of self-employed and employed income relate mainly to the possibility for the self-employed to underreport their income. In reality, however, the problem of varying burden on employees and the self-employed is not only a matter of income tax but also of social security contributions. In most EU

2 Since its first application in 1989, it has been used in at least 13 other studies. 
countries, the social security contributions of the self-employed are set in a different way than for people who are employed on a full-time basis. Provided that the social security contributions are not of an equivalent nature, it is these contributions that can determine the profitability of self-employment. The structure of the Polish social security system is based on a lump sum contribution for the self-employed and a proportional contribution for the employed. This shape of the system makes it more profitable to be employed at a low level of income. It is only above a certain level of income that lower contributions of the self-employed make self-employment more profitable. Taking into account the fact that the choice of the form of employment may be influenced not only by taxes, the studies presented herein also include social security contributions. Assuming that taxpayers act in a rational manner and that they are free to choose the form of provision of their work, they should adjust it to the amount of tax benefits available. These benefits depend to a large extent on the level of income received, but also on other individual factors determining the taxpayers' ability to benefit from tax preferences associated, for example, with being married or having dependent children. The EUROMOD microsimulation model and data from the European Union Statistics on Income and Living Conditions (EU-SILC) were used to calculate the tax benefits of self-employment. The first step is to determine the disposable income for the taxable persons surveyed, on the assumption that they derive their income from self-employment. The disposable income of the same taxable persons is then calculated on the assumption that the income they earn comes from employment. The tax benefit from self-employment is determined as the difference between disposable income from selfemployment and disposable income from full-time employment. The value of this benefit may be positive - if the level of self-employment burdens for a given taxpayer is lower than the level of burdens that a taxpayer would incur if he were employed on a full-time basis. Negative value of benefits occurs when it would be more profitable for a given taxpayer to take up employment on a full-time basis than to work on its own account.

The second step of the study is to construct a probit model of self-employment. In this model, the actual employment status of the taxpayer $(0-$ employed, $1-$ selfemployed) is assumed to be the explained variable. At the same time, the employed person is considered to be a person receiving income from employment or from employment and self-employment simultaneously. On the other hand, a person with income from sole self-employment is considered to be self-employed. The variables used as explanatory variables, besides tax benefits, are the values commonly used in the aforementioned studies, such as: age, gender (a binary variable where 0 means a woman and 1 means a man) and education level. In addition, eleven binary variables representing the sector of the economy in which the taxpayer is employed were also included. Tables 1 and 2 present descriptive statistics of the variables used. 
Table 1: Descriptive statistics for binary variables

\begin{tabular}{|c|c|c|c|c|c|c|c|c|}
\hline \multirow{3}{*}{ Variable } & \multirow{2}{*}{\multicolumn{2}{|c|}{$\begin{array}{c}2013 \\
\text { Variable }=1\end{array}$}} & \multirow{2}{*}{\multicolumn{2}{|c|}{$\begin{array}{c}2014 \\
\text { Variable }=1\end{array}$}} & \multirow{2}{*}{\multicolumn{2}{|c|}{$\begin{array}{c}2015 \\
\text { Variable }=1\end{array}$}} & \multirow{2}{*}{\multicolumn{2}{|c|}{$\begin{array}{c}2016 \\
\text { Variable }=1\end{array}$}} \\
\hline & & & & & & & & \\
\hline & Freq. & Per. (\%) & Freq. & Per. (\%) & Freq. & Per. (\%) & Freq. & Per. (\%) \\
\hline Self-employed & 3,105 & 21.23 & 2,846 & 20.87 & 2,710 & 20.21 & 2,926 & 20.23 \\
\hline Gender & 8,276 & 56.59 & 7,607 & 55.78 & 7,437 & 55.48 & 8,046 & 55.64 \\
\hline $\begin{array}{l}\text { Agriculture and } \\
\text { fisheries }\end{array}$ & 1,295 & 8.86 & 1,302 & 9.55 & 1,232 & 9.19 & 1,272 & 8.80 \\
\hline $\begin{array}{l}\text { Mining, manufac- } \\
\text { turing and utilities }\end{array}$ & 5,654 & 38.66 & 5,423 & 39.76 & 5,449 & 40.65 & 6,063 & 41.93 \\
\hline Construction & 990 & 6.77 & 865 & 6.34 & 832 & 6.21 & 842 & 5.82 \\
\hline $\begin{array}{l}\text { Wholesale and retail } \\
\text { trade }\end{array}$ & 1,586 & 10.85 & 1,399 & 10.26 & 1,329 & 9.91 & 1,453 & 10.05 \\
\hline $\begin{array}{l}\text { Hotels and } \\
\text { restaurants }\end{array}$ & 232 & 1.59 & 192 & 1.41 & 212 & 1.58 & 244 & 1.69 \\
\hline $\begin{array}{l}\text { Transport and } \\
\text { communication }\end{array}$ & 918 & 6.28 & 807 & 5.92 & 811 & 6.05 & 858 & 5.93 \\
\hline $\begin{array}{l}\text { Financial } \\
\text { intermediation }\end{array}$ & 299 & 2.04 & 284 & 2.08 & 268 & 2.00 & 257 & 1.78 \\
\hline $\begin{array}{l}\text { Real estate and } \\
\text { business activities }\end{array}$ & 731 & 5.00 & 653 & 4.79 & 633 & 4.72 & 721 & 4.99 \\
\hline $\begin{array}{l}\text { Public administration } \\
\text { and defence }\end{array}$ & 818 & 5.59 & 772 & 5.66 & 755 & 5.63 & 754 & 5.21 \\
\hline Education & 1,006 & 6.88 & 910 & 6.67 & 897 & 6.69 & 955 & 6.60 \\
\hline $\begin{array}{l}\text { Health and social } \\
\text { work }\end{array}$ & 778 & 5.32 & 734 & 5.38 & 694 & 5.18 & 712 & 4.92 \\
\hline $\begin{array}{l}\text { Number } \\
\text { of observations }\end{array}$ & & 14,624 & & 13,638 & & 13,406 & & 14,461 \\
\hline
\end{tabular}

Source: Own calculations based on the EU-SILC database 
Table 2: Descriptive statistics for other variables

\begin{tabular}{|c|c|c|c|c|c|}
\hline Year & Variable & Mean & Std. dev. & Min & $\operatorname{Max}$ \\
\hline \multirow{3}{*}{2013} & Taxadv & -114.01 & 397.24 & $-2,854.25$ & $4,371.94$ \\
\hline & Age & 42.17 & 12.52 & 16 & 80 \\
\hline & Level of education & 3.16 & 1.43 & 0 & 5 \\
\hline \multirow{3}{*}{2014} & Tax adv & 136.19 & 571.17 & $-2,974.29$ & $4,426.54$ \\
\hline & Age & 42.51 & 12.60 & 16.00 & 80.00 \\
\hline & Level of education & 3.09 & 1.51 & 0.00 & 5.00 \\
\hline \multirow{3}{*}{2015} & Tax adv & 128.58 & 579.15 & $-2,462.47$ & $4,451.47$ \\
\hline & Age & 42.58 & 12.71 & 16.00 & 80.00 \\
\hline & Level of education & 3.07 & 1.54 & 0.00 & 5.00 \\
\hline \multirow{3}{*}{2016} & Tax adv & 130.35 & 596.40 & $-3,474.80$ & $5,448.14$ \\
\hline & Age & 42.78 & 12.92 & 16.00 & 80.00 \\
\hline & Level of education & 3.05 & 1.56 & 0.00 & 5.00 \\
\hline
\end{tabular}

Source: Own calculations based on the EU-SILC database

As mentioned in most studies, a silent assumption is made that the self-employed persons' income reported for statistical purposes is not understated. However, as underlined above, there is no reason to expect that taxpayers report income for official statistics other than the declared tax return. Therefore, if there is underreporting in tax returns, it also applies to statistics. Therefore, in order to determine how the underreporting of income may affect the results of studies on the relationship between taxation and self-employment, the analysis will be carried out twice. The first time it will be using official data and the second time after adjustment for underreported income. The correction consists in that in the calculation of disposable income of the self-employed, the gross income reported by them is increased by a coefficient resulting from estimates of the phenomenon of income underreporting in Poland made by means of the P\&W method by Kukk et al. (2019). Contributions and taxes have been deducted from the gross income so determined on the assumption that they are determined on the basis of reported income.

The assumption made above that the income of all the self-employed is underrated to the same extent can be questioned. Therefore, the last stage of the study is to analyse the sensitivity of self-employment models to the level of income underrating, taking into account different income groups. 
In this part of the study, the reported income before taxes and social security contributions of the self-employed is increased gradually by 1 percentage point. Then, for the income adjusted in this way, the value of the benefit resulting from self-employment is determined. To do this, it is necessary to simulate, using the EUROMOD model, an income at the disposal of all taxpayers on the assumption that each of them is self-employed. Similar disposable income is then simulated on the assumption that each taxpayer is employed. By simulating the disposable income that employees can obtain by switching to self-employment, it is assumed that they can also obtain the benefit of concealing part of their income before tax. The difference between the disposable income that a taxpayer can obtain by becoming self-employed and the disposable income that he would obtain by becoming employed is an advantage from self-employment. The adjusted value of the tax benefit from self-employment is in turn used to estimate a new probit model of self-employment. This procedure of increasing the income of the self-employed by 1 percentage point, determining the benefits of self-employment and estimating the probit model of self-employment is repeated until the coefficient of the model for the variable determining the benefit of self-employment becomes positive. The level of income adjustment for which the coefficient of the model changes its sign to a positive is considered to be the probable amount of the income scale underreporting.

The test method used has certain limitations, which are largely due to the assumptions made. First of all, it has been assumed that taxpayers are perfectly rational and their decisions are guided only by the desire to maximise their disposable income. However, no account is taken of the fact that the income of the self-employed may be characterised by higher volatility than that of those who are employed. The second important assumption is that taxpayers are able to predict their future income accurately. It should be remembered that when deciding on the choice of the form of work provision, taxpayers are guided by the predicted and not the real level of income. Thirdly, it is assumed that only the self-employed underreport their income, while such a phenomenon may also occur in the category of employed people.

\section{Data and Results}

The results of the simulation of tax benefits resulting from the provision of work in the form of self-employment are used to construct a probit model.

The probit models used in the study are based on cross-section data - the inability to use panel data results from the fact that the research sample in EU-SILC studies changes every year. Some surveys based on similar data use pooled data but, given that the contributory and tax systems change every year, this type of approach seems inappropriate. Therefore, our analyses will be based on cross-section data. To check the stability of the results obtained, three models have been estimated for the years 2013-2016 (Table 3). 
Table 3: Probit regression of self-employment (uncorrected unadjusted data)

\begin{tabular}{|c|c|c|c|c|}
\hline Variable & 2016 & 2015 & 2014 & 2013 \\
\hline Tax advantage & $\begin{array}{l}-0.0004567^{* * *} \\
(0.0000258)\end{array}$ & $\begin{array}{l}-0.0004435^{* * *} \\
(0.0000272)\end{array}$ & $\begin{array}{l}-0.0004094^{* * *} \\
(0.0000267)\end{array}$ & $\begin{array}{l}-0.0004878^{* * *} \\
(0.0000267)\end{array}$ \\
\hline Age & $\begin{array}{l}0.0271736^{* * *} \\
(0.0010642)\end{array}$ & $\begin{array}{l}0.0265213^{* * *} \\
(0.0011104)\end{array}$ & $\begin{array}{l}0.0287989 * * * \\
(0.0011)\end{array}$ & $\begin{array}{l}0.0276921^{* * *} \\
(0.0010551)\end{array}$ \\
\hline Gender & $\begin{array}{l}0.4297341^{* * *} \\
(0.0303198)\end{array}$ & $\begin{array}{l}0.4051414^{* * *} \\
(0.0313742)\end{array}$ & $\begin{array}{l}0.4429438^{* * *} \\
(0.0308193)\end{array}$ & $\begin{array}{l}0.4610565^{* * *} \\
(0.0296518)\end{array}$ \\
\hline Level of education & $\begin{array}{l}0.1274269 * * * \\
(0.0107918)\end{array}$ & $\begin{array}{l}0.1278632 * * * \\
(0.0113275)\end{array}$ & $\begin{array}{l}0.1070504^{* * *} \\
(0.0112002)\end{array}$ & $\begin{array}{c}0.0967775^{* * *} \\
(0.0111)\end{array}$ \\
\hline Agriculture and fisheries & $\begin{array}{l}1.467559 * * * \\
(0.0893024)\end{array}$ & $\begin{array}{c}1.52243^{* * *} \\
(0.0942986)\end{array}$ & $\begin{array}{l}1.414371^{* * *} \\
(0.0938429)\end{array}$ & $\begin{array}{l}1.397596^{* * *} \\
(0.0894905)\end{array}$ \\
\hline $\begin{array}{l}\text { Mining, manufacturing } \\
\text { and utilities }\end{array}$ & $\begin{array}{l}-0.3611499 * * * \\
(0.0827285)\end{array}$ & $\begin{array}{l}-0.2803516^{* * *} \\
(0.0881752)\end{array}$ & $\begin{array}{c}-0.2563616^{* * *} \\
(0.0885644)\end{array}$ & $\begin{array}{c}-0.3007138^{* * *} \\
(0.0830326)\end{array}$ \\
\hline Construction & $\begin{array}{l}-0.1263469 \\
(0.0946884)\end{array}$ & $\begin{array}{l}-0.0112388 \\
(0.0990529)\end{array}$ & $\begin{array}{c}0.0160131 \\
(0.0986758)\end{array}$ & $\begin{array}{l}-0.1451718 \\
(0.0928724)\end{array}$ \\
\hline Wholesale and retail trade & $\begin{array}{l}-0.1163104 \\
(0.0882876)\end{array}$ & $\begin{array}{r}-0.0468291 \\
(0.0938741)\end{array}$ & $\begin{array}{l}-0.0289693 \\
(0.0938751)\end{array}$ & $\begin{array}{l}-0.1008047 \\
(0.0878692)\end{array}$ \\
\hline Hotels and restaurants & $\begin{array}{c}-0.2002984 \\
(0.1296508)\end{array}$ & $\begin{array}{l}-0.5597442^{* * *} \\
(0.1585975)\end{array}$ & $\begin{array}{l}-0.1325454 \\
(0.1433767)\end{array}$ & $\begin{array}{l}-0.1916072 \\
(0.1322013)\end{array}$ \\
\hline $\begin{array}{l}\text { Transport and } \\
\text { communication }\end{array}$ & $\begin{array}{l}-0.3524558^{* * *} \\
(0.0966816)\end{array}$ & $\begin{array}{c}-0.226296^{* *} \\
(0.1013079)\end{array}$ & $\begin{array}{c}-0.2389203^{* *} \\
(0.1016224) \\
\end{array}$ & $\begin{array}{c}-0.3543702^{* * *} \\
(0.0957946)\end{array}$ \\
\hline Financial intermediation & $\begin{array}{l}-0.31209 * * \\
(0.1329511)\end{array}$ & $\begin{array}{c}-0.2575934^{*} \\
(0.1364121)\end{array}$ & $\begin{array}{l}-0.1253958 \\
(0.1314087)\end{array}$ & $\begin{array}{c}-0.3069069^{* *} \\
(0.13117)\end{array}$ \\
\hline $\begin{array}{l}\text { Real estate and business } \\
\text { activities }\end{array}$ & $\begin{array}{c}-0.2923166^{* * *} \\
(0.0966201)\end{array}$ & $\begin{array}{c}-0.2016382^{*} \\
(0.1029938)\end{array}$ & $\begin{array}{c}-0.1585888 \\
(0.102414)\end{array}$ & $\begin{array}{c}-0.3083907^{* * *} \\
(0.0975136)\end{array}$ \\
\hline $\begin{array}{l}\text { Public administration } \\
\text { and defence }\end{array}$ & $\begin{array}{c}-0.7184685^{* * *} \\
(0.1068022)\end{array}$ & $\begin{array}{c}-0.7546826^{* * *} \\
(0.1133127)\end{array}$ & $\begin{array}{c}-0.6154869^{* * * *} \\
(0.109633)\end{array}$ & $\begin{array}{c}-0.6730362^{* * *} \\
(0.1052372)\end{array}$ \\
\hline Education & $\begin{array}{c}-0.6289594^{* * *} \\
(0.0984165)\end{array}$ & $\begin{array}{c}-0.5483303^{* * *} \\
(0.1042335)\end{array}$ & $\begin{array}{c}-0.5380382^{* * *} \\
(0.1048082)\end{array}$ & $\begin{array}{c}-0.5409274^{* * *} \\
(0.09837)\end{array}$ \\
\hline Health and social work & $\begin{array}{c}-0.3446619 * * * \\
(0.0992052)\end{array}$ & $\begin{array}{c}-0.3402538^{* * *} \\
(0.1051928)\end{array}$ & $\begin{array}{c}-0.2528767^{* *} \\
(0.1037652)\end{array}$ & $\begin{array}{c}-0.2511276^{* *} \\
(0.0978558)\end{array}$ \\
\hline Constant & $\begin{array}{l}-2.547413^{* * *} \\
(0.1022815) \\
\end{array}$ & $\begin{array}{l}-2.573658^{* * * *} \\
(0.1083973)\end{array}$ & $\begin{array}{l}-2.630035^{* * *} \\
(0.1083765)\end{array}$ & $\begin{array}{l}-2.46737^{* * *} \\
(0.1032571) \\
\end{array}$ \\
\hline $\mathbf{N}$ & 14,461 & 13,406 & 13,638 & 14,624 \\
\hline Pseudo $R^{2}$ & 0.2383 & 0.2345 & 0.224 & 0.2178 \\
\hline
\end{tabular}

Note: *Statistically significant at the $10 \%$ level, ${ }^{*}$ Statistically significant at the $5 \%$ level, ${ }^{* *}$ Statistically significant at the $1 \%$ level

Source: Own calculations based on the EU- SILC database 
The most important conclusion from the analysis of the model is that based on unadjusted data, the relationship between the tax benefit of self-employment and the likelihood of the taxpayer becoming self-employed is negative. Such a result appears to be inconsistent with logic and could indicate that taxpayers are unreasonable. However, if one takes into account the specificity of the Polish system of contributory and tax burdens, which makes self-employment profitable above a certain level of income, and the fact that data on self-employed income are underreported, the results obtained have a logical explanation. The self-employed reporting lower than actual incomes more often than the employed are below the self-employment profitability threshold.

The model analysis also shows that the probability of taking up self-employment increases with age. The willingness to work as a self-employed person is also positively correlated with the level of education. At the same time, the likelihood of becoming selfemployed is higher for men than for women. The results obtained for the influence of age, education and gender on the probability of taking up self-employment are consistent with the results of many previous studies, an overview of which can be found in Simoes et al. (2016). The analysis of the variables describing the sectors of the economy shows, however, that the probability of self-employment is higher only among people working in agriculture and fisheries. This is due to the fact that there is still a large fragmentation of farms in Poland. As a consequence, farmers account for a high share of the selfemployed in the statistics.

The high probability of underreporting of self-employed people's income may lead to the distortion of estimated self-employment models. Therefore, to check how underreporting income can affect self-employment models, tax benefits for adjusted income are simulated. The income adjustment is made on the basis of the results of Kukk et al. (2019) $)^{3}$ concerning estimates of the underreporting of self-employed income, assuming that the self-employed underreport their income by $15 \%$. The self-employment models were then re-estimated and the results are presented in Table 4.

3 These estimates show that the income of the self-employed in Poland is underreported by $10-20 \%$ in relation to the actual income. 
Table 4: Probit regression of self-employment (adjusted data)

\begin{tabular}{|c|c|c|c|c|}
\hline Variable & 2016 & 2015 & 2014 & 2013 \\
\hline Tax advantage & $\begin{array}{l}0.0003639 * * * \\
(0.000034)\end{array}$ & $\begin{array}{l}0.0004224^{* * *} \\
(0.0000378)\end{array}$ & $\begin{array}{l}0.0004791^{* * *} \\
(0.0000373)\end{array}$ & $\begin{array}{l}0.0004113^{* * * *} \\
(0.0000362)\end{array}$ \\
\hline Age & $\begin{array}{l}0.0283466^{* * *} \\
(0.0010797)\end{array}$ & $\begin{array}{l}0.027449 * * * \\
(0.0011245)\end{array}$ & $\begin{array}{l}0.0293953^{* * *} \\
(0.0011134)\end{array}$ & $\begin{array}{l}0.0271131^{* * * *} \\
(0.0010566)\end{array}$ \\
\hline Gender & $\begin{array}{l}0.2915026^{* * *} \\
(0.0299959)\end{array}$ & $\begin{array}{l}0.2542488^{* * * *} \\
(0.0310737)\end{array}$ & $\begin{array}{l}0.2923684^{* * *} \\
(0.0306563)\end{array}$ & $\begin{array}{l}0.3100317^{* * * *} \\
(0.0293641)\end{array}$ \\
\hline Level of education & $\begin{array}{l}0.0734972 * * * \\
(0.0103664)\end{array}$ & $\begin{array}{l}0.0690939 * * * \\
(0.0109305)\end{array}$ & $\begin{array}{l}0.0447197 * * * \\
(0.0108698)\end{array}$ & $\begin{array}{l}0.0310489 * * * \\
(0.0106555)\end{array}$ \\
\hline $\begin{array}{l}\text { Agriculture and } \\
\text { fisheries }\end{array}$ & $\begin{array}{c}1.217596 * * * \\
(0.0889979)\end{array}$ & $\begin{array}{c}1.211958^{* * *} \\
(0.0946993)\end{array}$ & $\begin{array}{c}1.151181^{* * *} \\
(0.0948188)\end{array}$ & $\begin{array}{c}1.08461^{* * *} \\
(0.0902508)\end{array}$ \\
\hline $\begin{array}{l}\text { Mining, manufac- } \\
\text { turing and utilities }\end{array}$ & $\begin{array}{l}-0.3928744^{* * *} \\
(0.0820759)\end{array}$ & $\begin{array}{c}-0.3266066^{* * *} \\
(0.087839)\end{array}$ & $\begin{array}{l}-0.288655^{* * *} \\
(0.0889737)\end{array}$ & $\begin{array}{c}-0.3590646^{* * *} \\
(0.0831639)\end{array}$ \\
\hline Construction & $\begin{array}{l}-0.2050741^{* *} \\
(0.0939876)\end{array}$ & $\begin{array}{l}-0.1066963 \\
(0.0988178)\end{array}$ & $\begin{array}{l}-0.0695494 \\
(0.0991925)\end{array}$ & $\begin{array}{c}-0.2426142^{* * *} \\
(0.0929874)\end{array}$ \\
\hline $\begin{array}{l}\text { Wholesale and } \\
\text { retail trade }\end{array}$ & $\begin{array}{l}-0.1203577 \\
(0.0876464)\end{array}$ & $\begin{array}{c}-0.0576298 \\
(0.093647)\end{array}$ & $\begin{array}{l}-0.0106887 \\
(0.0943803)\end{array}$ & $\begin{array}{l}-0.1339635 \\
(0.0880475)\end{array}$ \\
\hline $\begin{array}{l}\text { Hotels and } \\
\text { restaurants }\end{array}$ & $\begin{array}{l}-0.1690281 \\
(0.1297452)\end{array}$ & $\begin{array}{c}-0.5590791^{* * *} \\
(0.1617108)\end{array}$ & $\begin{array}{l}-0.1070848 \\
(0.1452435)\end{array}$ & $\begin{array}{c}-0.2479013^{*} \\
(0.1333172)\end{array}$ \\
\hline $\begin{array}{l}\text { Transport and } \\
\text { communication }\end{array}$ & $\begin{array}{l}-0.5003421^{* * *} \\
(0.0957679)\end{array}$ & $\begin{array}{c}-0.3747926^{* * *} \\
(0.1008753)\end{array}$ & $\begin{array}{c}-0.3582831^{* * *} \\
(0.101872)\end{array}$ & $\begin{array}{c}-0.5015844^{* * *} \\
(0.0955088)\end{array}$ \\
\hline $\begin{array}{l}\text { Financial } \\
\text { intermediation }\end{array}$ & $\begin{array}{c}-0.5480619 * * * \\
(0.1307652)\end{array}$ & $\begin{array}{c}-0.4886244^{* * *} \\
(0.1336615)\end{array}$ & $\begin{array}{c}-0.3690912 * * * \\
(0.1299323)\end{array}$ & $\begin{array}{c}-0.6172717^{* * *} \\
(0.129379)\end{array}$ \\
\hline $\begin{array}{l}\text { Real estate and } \\
\text { business activities }\end{array}$ & $\begin{array}{l}-0.3283706^{* * *} \\
(0.0960327)\end{array}$ & $\begin{array}{c}-0.2505006^{* *} \\
(0.1027504)\end{array}$ & $\begin{array}{c}-0.2000334^{*} \\
(0.1028897)\end{array}$ & $\begin{array}{c}-0.3869656^{* * *} \\
(0.0976243)\end{array}$ \\
\hline $\begin{array}{l}\text { Public administra- } \\
\text { tion and defence }\end{array}$ & $\begin{array}{l}-1.00362^{* * *} \\
(0.1069678)\end{array}$ & $\begin{array}{l}-1.008159^{* * *} \\
(0.1132464)\end{array}$ & $\begin{array}{c}-0.8671949 * * * \\
(0.1102792)\end{array}$ & $\begin{array}{l}-0.9633754^{* * *} \\
(0.1057229)\end{array}$ \\
\hline Education & $\begin{array}{l}-0.8190959 * * * \\
(0.0981305)\end{array}$ & $\begin{array}{l}-0.799511^{* * *} \\
(0.1044961)\end{array}$ & $\begin{array}{c}-0.7495036^{* * *} \\
(0.1055951)\end{array}$ & $\begin{array}{c}-0.8014739 * * * \\
(0.098833)\end{array}$ \\
\hline $\begin{array}{l}\text { Health and social } \\
\text { work }\end{array}$ & $\begin{array}{c}-0.4880031^{* * *} \\
(0.0990223)\end{array}$ & $\begin{array}{c}-0.4937388^{* * *} \\
(0.1055271)\end{array}$ & $\begin{array}{c}-0.3953327^{* * *} \\
(0.1046611)\end{array}$ & $\begin{array}{c}-0.4550543^{* * *} \\
(0.0981917)\end{array}$ \\
\hline Constant & $\begin{array}{l}-2.250173^{* * *} \\
(0.1017948)\end{array}$ & $\begin{array}{l}-2.211585^{* * *} \\
(0.1084701)\end{array}$ & $\begin{array}{l}-2.26531^{* * *} \\
(0.1089479)\end{array}$ & $\begin{array}{l}-2.001244^{* * *} \\
(0.1031525)\end{array}$ \\
\hline $\mathbf{N}$ & 14,461 & 13,406 & 13,638 & 14,642 \\
\hline Pseudo $R^{2}$ & 0.2228 & 0.2225 & 0.2181 & 0.2024 \\
\hline
\end{tabular}

Note: *Statistically significant at the $10 \%$ level, ${ }^{* *}$ Statistically significant at the $5 \%$ level, ${ }^{* *}$ Statistically significant at the $1 \%$ level

Source: Own calculations based on the EU- SILC database 
The analysis of the self-employment models estimated on the basis of the adjusted data on self-employed income leads to the conclusion that tax savings from self-employment are an important incentive for taking up self-employment. It should be emphasized here that this concerns both savings resulting from official preferences and benefits resulting from the possibility of understating tax income. Inclusion of the phenomenon of underreporting income in the study not only changes the sign of the coefficient for the variable describing the tax benefit from self-employment, but also changes the significance of other variables in the model. This concerns binary variables describing sectors such as construction, hotels and restaurants, health and social work. However, in the case of changes in the significance of the binary variable representing the construction sector, one can observe instability of the results over time. This may be due to at least two reasons. The first reason is that the sample used in the EU-SILC survey changes from year to year. However, the question arises why similar effects are not seen in other sectors. The second possible reason is a change in the employment policy of large construction companies. Along with changes in the economic situation on the construction market, there also occur changes on the labour market for construction workers. At times of greater demand for workers, companies try to tie up their employees more strongly, employing them on a full-time basis. In periods of economic downturn, large companies prefer to employ subcontractors running their own businesses.

As already mentioned, the assumption that the scale of income concealment is identical for all self-employed people may be controversial. Therefore, in addition, an analysis of the impact of a gradual adjustment of self-employed persons' income on the parameters of the probit model of self-employment, including the division of the selfemployed according to income groups, is carried out (the detailed procedure is described in the previous section). Results of calculations for particular income quartiles are presented in Table 5.

As can be seen, the percentage of income underreporting varies according to the level of income received. In all the years analysed, taxpayers in the second income quartile were underreporting their income to the least extent and taxpayers in the highest quartile to the greatest extent. This conclusion is at least partly consistent with previous studies. The average level of income underreporting for all taxpayers falls between $10 \%$ and $11 \%$. It should be stressed that the level of the scale of income underreporting by the selfemployed may also depend on characteristics other than income such as sex, education level, sector, age, etc. However, due to the limited size of the article, it is not possible to present analyses for all these factors. 
Table 5: Underreporting rate of self-employed income by quartile of gross income (\%)

\begin{tabular}{l|c|c|c|c}
\hline Gross income quartile & $\mathbf{2 0 1 3}$ & $\mathbf{2 0 1 4}$ & $\mathbf{2 0 1 5}$ & $\mathbf{2 0 1 6}$ \\
\hline $\mathbf{1}$ & 9 & 7 & 9 & 8 \\
\hline $\mathbf{2}$ & 5 & 1 & 4 & 7 \\
\hline $\mathbf{3}$ & 13 & 11 & 10 & 10 \\
\hline $\mathbf{4}$ & 14 & 14 & 14 & 13 \\
\hline All & 11 & 10 & 10 & 11 \\
\hline
\end{tabular}

Source: Own calculations based on the EU-SILC database

\section{Conclusions}

The analysis of the literature on self-employment shows that this is an important problem for the economy. Although the positive impact of self-employment on the economy is sometimes questioned, most arguments lead to the conclusion that it has more advantages than disadvantages. More recent literature on the subject, however, draws attention to the need for a selective approach to promoting self-employment. The use of specific instruments to support self-employment should be preceded by a thorough evaluation of the effectiveness of the instruments used. Tax policy is one of the tools used most frequently to support self-employment. Existing studies on the impact of taxes on selfemployment lead to very diverse and often contradictory conclusions. This diversity may be due to a number of reasons, such as the use of different methods and datasets. Not without significance is the fact that the analyses are carried out for different periods of time and for different countries. This article investigates whether the results of studies on the relationship between taxation and self-employment may be affected by income underreporting. The presented analyses show that data on self-employed persons' income presented in statistics may be understated. Consequently, analysis of models based on misrepresented data can lead to unsatisfactory conclusions. This problem disappears when the analysis takes into account the adjustment of self-employed people's income with underreported income. From the models based on adjusted data, it can be concluded that the tax benefits that can be obtained from self-employment positively influence the propensity to become self-employed. However, the results obtained cannot be used as an argument for state support for self-employment through tax incentives. This is because informal tax benefits can play a key role in deciding whether to start self-employment.

An analysis of the model sensitivity to income underreporting shows that in the case of Poland, the self-employed underreport their income by at least $10 \%$, which is in line with the estimates of Kukk et al. (2019). 
It should be stressed that the phenomenon of income underreporting may affect not only the results of research into the impact of taxation on self-employment, but also other determinants of self-employment.

\section{References}

Artavanis, N., Morse, A., Tsoutsoura, M. (2016). Measuring Income Tax Evasion Using Bank Credit: Evidence from Greece. The Quarterly Journal of Economics, 131(2), 739-798, https://doi.org/10.1093/qje/qjw009

Blau, D. M. (1987). A Time-Series Analysis of Self-Employment in the United States. Journal of Political Economy, 95(3), 445-467.

Bruce, D. (2000). Effects of the United States Tax System on Transitions into Self-employment. Labour Economics, 7(5), 545-574, https://doi.org/10.1016/S0927-5371(00)00013-0

Crum, M., Gohmann, S. (2016). The Impact of Taxes and Regulations on Firm Births and Deaths in State Border Counties. Journal of Entrepreneurship and Public Policy, 5, 25-37, https://doi.org/10.1108/JEPP-06-2014-0025

Domar, E. D., Musgrave, R. A. (1944). Proportional Income Taxation and Risk-Taking. The Quarterly Journal of Economics, 58(3), 388-422, https://doi.org/10.2307/1882847

Dondena, CASE, IEB, PWC (2017). Literature Review on Taxation, Entrepreneurship and Collaborative Economy. European Union. Luxembourg Taxation Papers Working Paper No. 70, https://doi.org/10.2778/924259

Egebark, J. (2016). Effects of Taxes on Youth Self-Employment and Income. IFN. Working Paper No. 1117, https://doi.org/10.2139/ssrn.2766582

Engström, P., Hagen, J. (2017). Income Underreporting Among the Self-employed:

A Permanent Income Approach. European Economic Review, 92, 92-109, https://doi.org/10.1016/j.euroecorev.2016.12.001

Fossen, F. M., Steiner, V. (2009). Income Taxes and Entrepreneurial Choice: Empirical Evidence from two German Natural Experiments. Empirical Economics, 36(3), 487-513, https://doi.org/10.1007/s00181-008-0208-z

Gentry, W. M., Hubbard, R. G. (2000). Tax Policy and Entrepreneurial Entry. The American Economic Review, 90(2), 283-287, https://doi.org/10.1257/aer.90.2.283

Hansson, Å. (2010). Tax Policy and Entrepreneurship: Empirical Evidence from Sweden. Small Business Economics, 38(4), 495-513, https://doi.org/10.1007/s11187-010-9282-7

Hurst, E., Li, G., Pugsley, B. (2013). Are Household Surveys Like Tax Forms? Evidence from Income Underreporting of the Self-Employed. The Review of Economics and Statistics, 96(1), 19-33, https://doi.org/10.1162/REST_a_00363

Kanbur, S. M. (1981). Risk Taking and Taxation: An Alternative Perspective. Journal of Public Economics, 15(2), 163-184, https://doi.org/10.1016/0047-2727(81)90031-1 
Kleven, H. J., Knudsen, M. B., Kreiner, C. T., et al. (2011). Unwilling or Unable to Cheat? Evidence from a Tax Audit Experiment in Denmark. Econometrica, 79(3), 651-692, https://doi.org/10.3982/ECTA9113

Kukk, M., Paulus, A., Staehr, K. (2019). Income Underreporting by the Self-employed in Europe: A Cross-country Comparative Study. Bank of Estonia. Tallin Working Papers No. wp201804. Available at: https://ideas.repec.org/p/eea/boewps/wp2018-04.html

Long, J. E. (1982). Income Taxation and the Allocation of Market Labor. Journal of Labor Research, 3(3), 259-276, https://doi.org/10.1007/BF02685189

Parker, S. (1996). A Time Series Model of Self-Employment under Uncertainty. Economica, 63(251), 459-475, https://doi.org/10.2307/2555017

Parker, S. C. (2003). Does Tax Evasion Affect Occupational Choice?*. Oxford Bulletin of Economics and Statistics, 65(3), 379-394, https://doi.org/10.1111/1468-0084. t01-1-00050

Parker, S. C., Robson, M. T. (2004). Explaining International Variations in Self-Employment: Evidence from a Panel of OECD Countries. Southern Economic Journal, 71(2), 287-301, https://doi.org/10.2307/4135292

Pissarides, C. A., Weber, G. (1989). An expenditure-based Estimate of Britain's Black Economy. Journal of Public Economics, 39(1), 17-32, https://doi.org/10.1016/0047-2727(89)90052-2

Robson, M. T., Wren, C. (1999). Marginal and Average Tax Rates and the Incentive for Self-Employment. Southern Economic Journal, 65(4), 757-773, https://doi. org/10.2307/1061274

Schuetze, H. J. (2000). Taxes, Economic Conditions and Recent Trends in Male Selfemployment: A Canada-US Comparison. Labour Economics, 7(5), 507-544, https://doi.org/10.1016/S0927-5371(00)00012-9

Simoes, N., Crespo, N., Moreira, S. B. (2016). Individual Determinants of Self-Employment Entry. Journal of Economic Surveys, 30(4), 783-806, https://doi.org/10.1111/joes.12111

Torrini, R. (2005). Cross-country Differences in Self-employment Rates: The Role of Institutions. Labour Economics, 12(5), 661-683, https://doi.org/10.1016/j. labeco.2004.02.010

Wagner, J., Sternberg, R. (2004). Start-up Activities, Individual Characteristics, and the Regional Milieu: Lessons for Entrepreneurship Support Policies from German Micro Data. The Annals of Regional Science, 38(2), 219-240, https://doi.org/10.1007/ s00168-004-0193-x

Wen, J. F., Gordon, D. V. (2014). An Empirical Model of Tax Convexity and Self-Employment. Review of Economics and Statistics, 96(3), 471-482. 